Pak. j. sci. ind. res. Ser. B: biol. sci. 201255 (3) 117-121

\title{
Effect of Foliar Applied Boron Application on Growth, Yield and Quality of Maize (Zea mays L.)
}

\author{
Muhammad Tahir ${ }^{a}$, Asghar Ali ${ }^{a}$, Farhan Khalid ${ }^{a}$, Muhammad Naeem ${ }^{b}$, \\ Naeem Fiaz $^{a}$ and Muhammad Waseem ${ }^{\text {a* }}$ \\ ${ }^{a}$ Department of Agronomy, University of Agriculture, Faisalabad, Pakistan \\ ${ }^{b}$ University College of Agriculture and Environmental Sciences, Islamia University, Bahawalpur, Pakistan
}

(received April 7, 2011; revised December 17, 2011; accepted January 9, 2012)

\begin{abstract}
A field study was carried out to evaluate the effect of foliar applied boron application on growth, yield and quality of maize (Zea mays L.). Foliar application of boron was carried out after 20 days of crop emergence at $0,0.15,0.30$ and $0.45 \mathrm{~kg}$ of $\mathrm{B} / \mathrm{ha}$. Boron application at $0.30 \mathrm{~kg} / \mathrm{ha}$ increased the plant height, leaf area, stem diameter, cob weight, number of grains per cob, protein and oil contents. The maximum grain yield (7.14 tons/ha) and biological yield (527.4 tons/ha) was recorded in $\mathrm{B}_{2}$ where application of boron was carried out at $0.30 \mathrm{~kg} / \mathrm{ha}$, however, further increase in boron dose decreased the yields.
\end{abstract}

Keywords: maize, hybrid, boron, foliar spray, cereal, micronutrient

\section{Introduction}

Cereals are important components of human diet providing $65 \%$ of the energy requirements. The cultivation and domestication of these crops has long standing history. Among cereal crops, maize is at the top in terms of its production share. However in Pakistan, it ranks third after wheat and rice. Presently it is grown approximately on 1015 thousand hectares with total production of 3313 thousand tons (NNS, 2008). Maize cultivation is beneficial as its processing yield several products that have the important industrial applications (Bressani et al., 2004) resulting in its increased demand. There are several factors that play dominant role in enhancing its yield; proper and balance fertilization is one of the important factors in increasing the yield and quality of the crop. The present scenario suggests that application of macronutrients is also essential along with macronutrients to get the desired results with respect to biological and grain yield. Moreover, Pakistani soils are deficient in boron, zinc etc. (Hussain et al., 2006).

Boron deficiency in crops is more widespread than that of the other micronutrients (Gupta et al., 1985). Boron is closely associated with the growth of plants and plays a vital role in cell division. Moreover, requirements of boron vary according to species, crops and stages i.e. reproduction and vegetative. The requirement of boron to crops is affected by several environmental factors like temperature, light and soil water conditions

\footnotetext{
*Author for correspondence; E-mail: mianwaseem_1028@yahoo.com
}

(Shorrocks, 1997). Deficiency symptoms of boron can be observed in vegetative and reproductive parts such as inhibition of growth of shoot and root tips, flower development, reduced setting and malformation of seeds. However, application of boron require thorough analysis of requirements as excessive application of boron is toxic for plant growth (Dell and Huang, 1997; Sherrell, 1983). The present study was carried out to investigate the influence of foliar applied boron concentrations on growth and yield of maize hybrid.

\section{Materials and Methods}

The field experiment was conducted at Agronomic Research Area, University of Agriculture, Faisalabad, during spring 2008 to evaluate the influence of foliar applied boron concentrations on growth and yield of maize (Zea mays L.) hybrid. A factorial experiment was organized in randomized complete block design (RCBD) with four replications having net plot size of $6 \mathrm{~m} \times 3 \mathrm{~m}$. Maize hybrid Monsanto-6525 was sown in $2^{\text {nd }}$ week of March in $75 \mathrm{~cm}$ apart ridges in hills $30 \mathrm{~cm}$ apart at one side of the ridge using seed rate of $25 \mathrm{~kg} / \mathrm{ha}$. The fertilizers were applied at $250-125-125 \mathrm{~kg} / \mathrm{NPK} / \mathrm{ha}$ as Urea, DAP and SSP, respectively, dose of phosphorous and potash and half dose of nitrogen at sowing and remaining half nitrogen dose was applied at top dressed at knee height. Boron was applied at 0, 0.15, 0.30 and $0.45 \mathrm{~kg} / \mathrm{ha}$ as foliar spray 20 days after crop emergence. Soil samples were taken before sowing of crop to a depth of $30 \mathrm{~cm}$ for physiochemical analysis. Soil was loamy type with $\mathrm{pH}$ of 7.87 , EC of $2.16 \mathrm{dSm}$ and SAR 
$440 \mathrm{ppm}$. Likewise, it contained organic matter $(0.49 \%)$, phosphorous (4.08 ppm), potassium (273 ppm) and boron $(0.32 \mathrm{mg} / \mathrm{kg})$. This analysis showed that soil deficient in boron contents can not meets the requirements of maize crop. All other agronomic practices were kept normal and uniform for all the treatments.

Growth and yield parameters. Plant height $(\mathrm{cm})$, leaf area $\left(\mathrm{cm}^{2}\right)$, stem diameter $(\mathrm{cm})$, cob weight $(\mathrm{g})$, cob length $(\mathrm{cm})$, cob diameter $(\mathrm{cm})$, number of grains per cob, 100 grain weight (g), grain rows per cob, biological yield (tons/ha), grain yield (tons/ha), protein contents $(\%)$ and oil contents (\%) were recorded. Data collected were analyzed statistically using Fisher's analysis of variance technique. Difference among the treatment means was compared using least significant difference at $5 \%$ probability level (Steel et al., 1997).

\section{Results and Discussion}

Indices of growth. The growth indices of maize indicated the significant influence of boron application. The increasing tendency in plant height, leaf area and stem diameter was observed from 153.4 to $163.1 \mathrm{~cm}$, 15.82 to $19.00 \mathrm{~cm}^{2}$ and 1.867 to $3.138 \mathrm{~cm}$, respectively, when boron was applied @ $0.30 \mathrm{~kg} / \mathrm{ha}$ (Table 1). The maximum plant height, leaf area and stem diameter were recorded where boron was applied @ $0.30 \mathrm{~kg} / \mathrm{ha}$ with mean values of $163.1 \mathrm{~cm}, 19.0 \mathrm{~cm}^{2}$ and $3.138 \mathrm{~cm}$, respectively. However, increasing the dose of boron from 0.30 to $0.45 \mathrm{~kg} / \mathrm{ha}$, resulted in significant declining in all attributes of growth but was still significantly higher as compared to control.

Cob characteristics. Cob characteristics include cob weight $(\mathrm{g})$, cob length $(\mathrm{cm})$ and cob diameter $(\mathrm{cm})$. These all parameters are indicator of better yield performance. The cob weight showed significant results with an increasing trend with increasing concentrations of boron (Fig. 1). Both the higher and lower levels of boron where boron was applied @ 0.15 and $0.45 \mathrm{~kg} / \mathrm{ha}$, respectively, decreased the cob weight significantly when compared with boron applied @ $0.30 \mathrm{~kg} / \mathrm{ha}$. The cob length was not affected significantly by boron application and values were in the range of 19.97 to $21.57 \mathrm{~cm}$. The relationship of cob diameter showed a slightly increasing trend increasing concentration of boron (Fig. 2). Maximum cob diameter was recorded in fields where foliar spray of boron @ $0.30 \mathrm{~kg} / \mathrm{ha}$ was applied. However, differences among different boron levels were not significant.

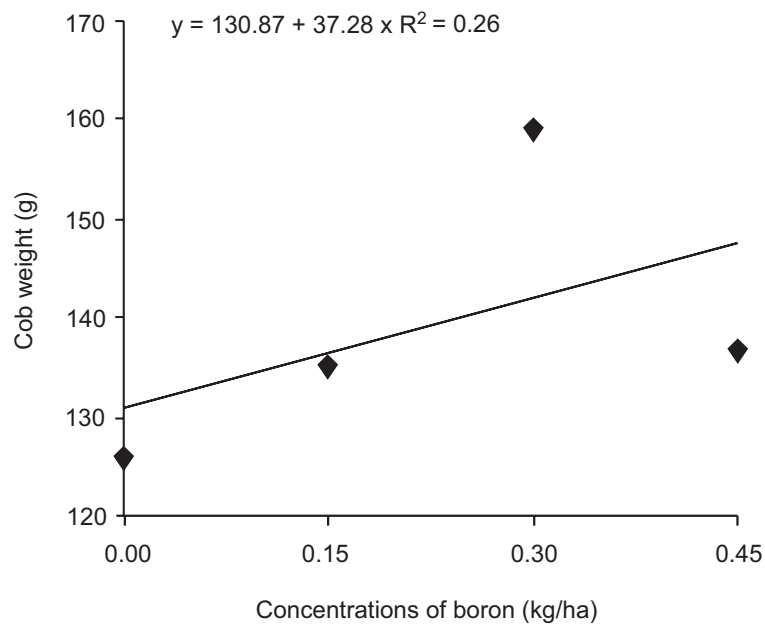

Fig. 1. Effect of foliar applied boron concentrations on cob weight.

Yield indices. The yield indices include number of grains per cob, 100 grain weight, grain rows per cob, biological yield and grain yield. Data concerning number

Table 1. Effect of foliar applied boron application on growth, yield and quality of maize at maturity stage

\begin{tabular}{|c|c|c|c|c|c|c|c|c|c|}
\hline Treatments & $\begin{array}{l}\text { Plant } \\
\text { height } \\
(\mathrm{cm})\end{array}$ & $\begin{array}{l}\text { Leaf } \\
\text { area } \\
\left(\mathrm{cm}^{2}\right)\end{array}$ & $\begin{array}{l}\text { Stem } \\
\text { diameter } \\
(\mathrm{cm})\end{array}$ & $\begin{array}{l}\text { Cob } \\
\text { length } \\
(\mathrm{cm})\end{array}$ & $\begin{array}{l}\text { Grain } \\
\text { rows/ } \\
\text { cob }\end{array}$ & $\begin{array}{l}\text { Biological } \\
\text { yield } \\
\text { (tons/ha) }\end{array}$ & $\begin{array}{l}\text { Grain } \\
\text { yield } \\
\text { (tons/ha) }\end{array}$ & $\begin{array}{l}\text { Protein } \\
\text { contents } \\
(\%)\end{array}$ & $\begin{array}{l}\text { Oil } \\
\text { contents } \\
(\%)\end{array}$ \\
\hline $\mathrm{B}_{0}=$ Control & $153.4 \mathrm{c}$ & $15.82 \mathrm{~d}$ & $1.867 \mathrm{c}$ & 19.97 & 14.50 & $333.1 \mathrm{c}$ & $6.045 \mathrm{~d}$ & $9.50 \mathrm{c}$ & $4.39 c$ \\
\hline $\mathrm{B}_{1}=0.15 \mathrm{~kg} / \mathrm{ha}$ & $159.1 \mathrm{~b}$ & $16.77 \mathrm{c}$ & $2.395 b$ & 21.27 & 15.50 & $430.4 b$ & $6.883 b$ & $10.62 b$ & $4.71 b$ \\
\hline $\mathrm{B}_{2}=0.30 \mathrm{~kg} / \mathrm{ha}$ & $163.1 \mathrm{a}$ & $19.00 \mathrm{a}$ & $3.138 \mathrm{a}$ & 21.53 & 15.54 & $527.4 \mathrm{a}$ & $7.145 \mathrm{a}$ & $11.23 \mathrm{a}$ & $4.84 \mathrm{a}$ \\
\hline $\mathrm{B}_{3}=0.45 \mathrm{~kg} / \mathrm{ha}$ & $157.4 \mathrm{~b}$ & $17.65 b$ & $2.557 \mathrm{~b}$ & 21.57 & 14.32 & $426.8 b$ & $6.523 c$ & $10.57 \mathrm{~b}$ & $4.35 c$ \\
\hline F-value & $18.7704 * *$ & $33.594 * *$ & $55.2245 * *$ & $1.138 \mathrm{~ns}$ & $0.603 \mathrm{~ns}$ & $37.305 * *$ & $87.0512 * *$ & $30.6768 * *$ & $53.0804 * *$ \\
\hline LSD value & 2.978 & 0.7451 & 0.2262 & -- & -- & 41.54 & 0.160 & 0.4140 & 0.1012 \\
\hline
\end{tabular}

Mean values in column not comprising the same letter $(a, b, c, d)$ vary significantly at $(\mathrm{P}=0.05)$; ** $=$ highly significant at $5 \%$ level; ns = non significant. 


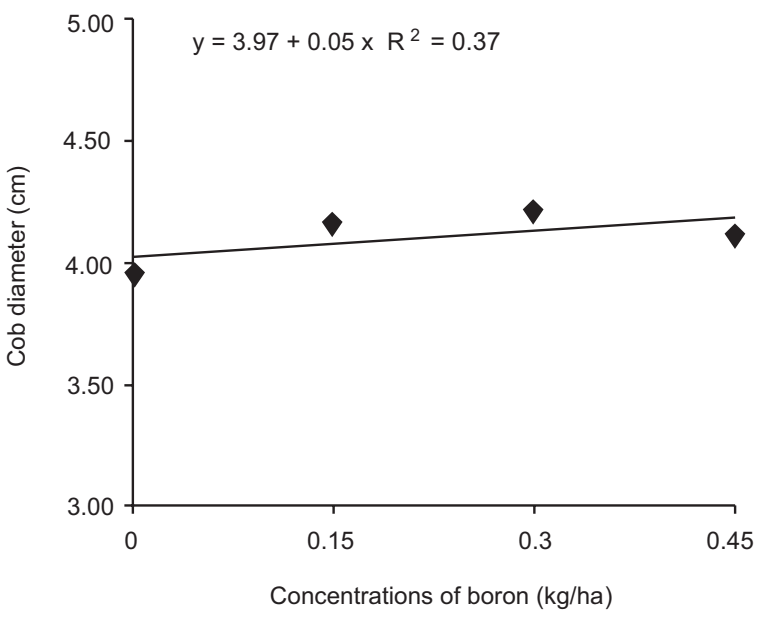

Fig. 2. Effect of foliar applied boron concentrations on cob diameter.

of grains per cob showed highly significant results and its linear relationship showed an increasing trend with different boron concentrations (Fig. 3). Relationship showed that with the increase in boron concentration there was an increase in number of grains per cob up to a certain level while its excessive dose lowered the number of grains. Application of boron significantly increased the number of grains per cob compared to control. The difference among different boron levels could not reach to the level of significance.

The data pertaining to 100 grain weight when subjected to statistical analysis revealed significant differences among treatments. The attribute increased progres-

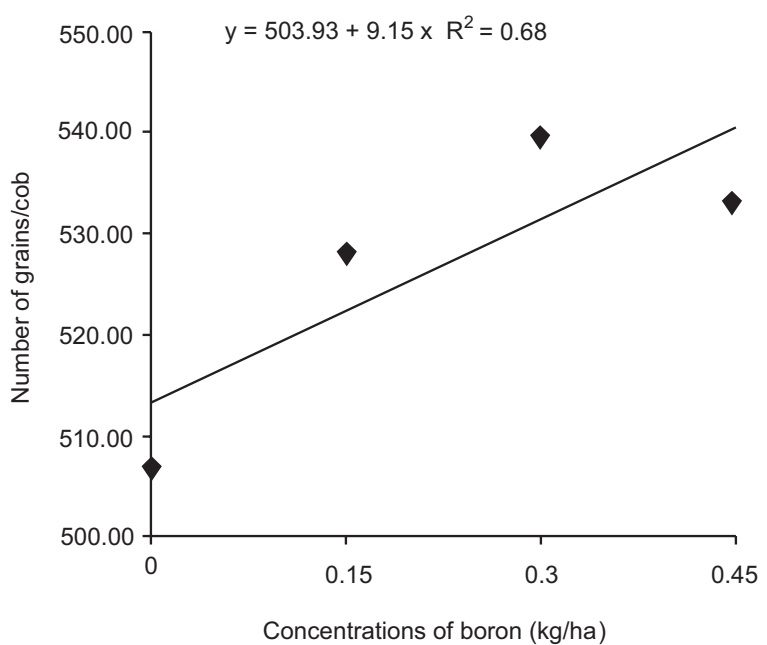

Fig. 3. Effect of foliar applied boron concentrations on number of grains per cob. sively and hold linear relationship with born application (Fig. 4). The increased boron dose from 1.5 to $0.45 \mathrm{~kg} / \mathrm{ha}$ significantly decreased the 100 grain weight which, however was statistically similar to the $0.15 \mathrm{~kg} / \mathrm{ha}$. The minimum 100 grain weight was recorded in control treatment. In contrary, number of grain rows per cob was not significantly affected due to foliar application of boron at varying doses (Table 1).

As far as biological and grain yields are concerned, foliar application of born improved the biological yield significantly. The lowest biological yield of 333.1 tons/ha was recorded in control fields as compared to maximum (527.4 tons/ha) in maize subjected to foliar application of boron@0.30 kg/ha. Moreover, boron@0.15 and $0.45 \mathrm{~kg} / \mathrm{ha}$ were statistically at par with mean yield of 430.4 and 426.8 tons/ha, respectively. Foliar application of boron showed highly significant results for grain yield. Comparison of mean values (Table 1) showed that maximum grain yield of 7.14 tons/ha was recorded when boron was applied @ $0.30 \mathrm{~kg} /$ ha followed by boron applied@0.15 kg/ha (6.88 tons/ha). The increase in boron level from 1.5 to $0.45 \mathrm{~kg} / \mathrm{h}$ a resulted in sharp reduction in grain yield and grain yield obtained from $\mathrm{B}_{3}$ (6.52 tons/ha) was significantly lower from $\mathrm{B}_{2}$ (7.145 tons/ha) and $\mathrm{B}_{1}(6.88$ tons/ha) while the least grain yield was recorded in control (6.04 tons/ha) where boron was not applied.

Qualitative traits. Boron application significantly affected protein contents of grains and maximum protein

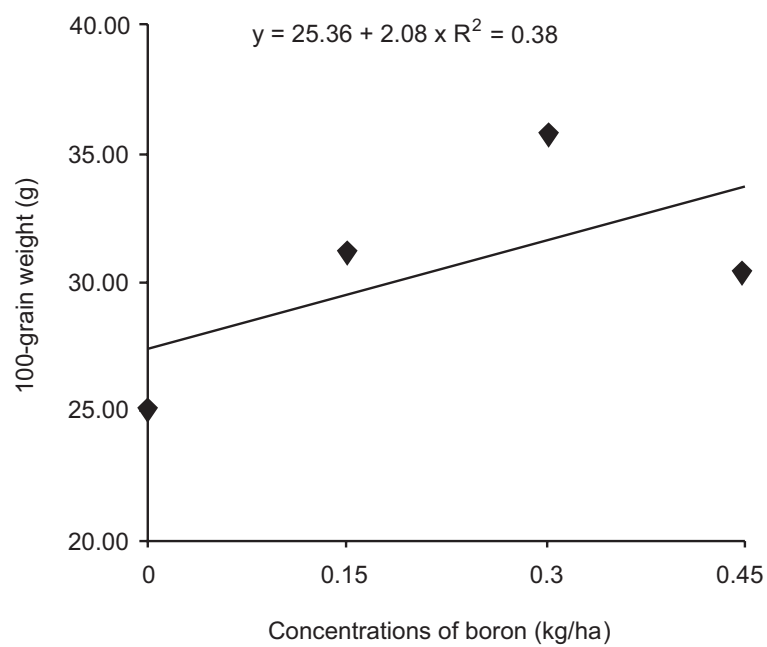

Fig. 4. Effect of foliar applied boron concentrations on 100-grains weight. 
contents $(11.23 \%)$ were recorded where boron was applied@0.30 kg/ha while higher and lower doses, than this, were found to be similar with mean oil contents of 10.62 and $10.57 \%$, but were higher than control $(9.50 \%)$ where boron application was not carried out (Table 1).

Oil contents is an important factor that contributes towards the yield and boron application at various rates showed momentous effect on oil contents (Table 1). Boron application @ $0.30 \mathrm{~kg} /$ ha showed maximum oil contents (4.84\%) followed by $\mathrm{B}_{2}(4.71 \%)$ where boron was applied @ $0.15 \mathrm{~kg} / \mathrm{ha}$. While higher dose of $0.45 \mathrm{~kg} /$ ha showed similar results to control with oil contents of 4.35 and 4.39 , respectively.

Boron has been found to be an essential micronutrient element for plant growth and development. Previous studies showed that boron is a micronutrient that is essential for plant only but recent research work carried out by different research workers had shown that boron is essential for animals especially human beings because of its key role in synthesis of estrogen, vitamin D and other steroid hormones.

Indices of growth. In this study, increasing concentration of boron significantly affected the growth parameter like plant height, leaf area and stem diameter. Momentous increase recorded in growth indices of maize plants might be due to its vital role in cell wall synthesis, division, elongation and nucleic acid metabolism. Reduction in mean values recorded for growth parameters at higher dosage of boron application could be due to the burning effect of boron noted on leaves. Findings of present research are well in agreement with that of Ceyhan et al. (2007) and Mazher et al. (2006). They are of the view that boron application improves the growth parameters significantly. Moreover, Ahmed et al. (2008) also highlighted the role of boron applied at various rates and found significant improvements in growth indices. Similar results were also reported by Lopez-Lefebre et al. (2002) who reported marked differences among the means regarding biomass production.

Cob characteristics. Cob characteristics include cob weight, cob length, cob diameter and number of gains per cob and these parameters contribute towards the final yield. The improvements in cob characteristics of maize hybrid bolster the prospects of boron applications for the enhancement of growth and maize yield. The momentous effect of boron application was found regarding the cob related features of the maize plants. This significant effect of boron application might be due to its vital role in pollen tube formation, increasing the efficiency of fertilization process, which may results in variability among the mean values regarding cob weight, cob diameter and number of grains per cob. This may result in improvement of the grain size of the plants.

These results are in accordance with Gupta (1993), who reported that boron is required continuously for growth of most of the plants otherwise deficiency occurs. The reduction in cob weight at higher dose may be due to the toxic effects of boron leading to burning of leaf margins and affecting adversely the photosynthetic activity of plant while in control reduction in cob weight may be due to the deficiency of boron. The results indicated that boron has significant effect on number of grains per cob while in case of deficiency the number of grains per cob may reduce.

Yield indices. The yield indices include 100 grain weight, grain rows per cob, biological yield and grain yield. The improvement in grain and biological yield of maize hybrids is mainly attributed to complementary role of boron in the reproduction and vegetative stage of plants. Usually, micronutrients are required in minute amounts but impart significant effects on metabolism by working synergistically with hormones and enzymes in normal functionality of system. The present findings are well in agreement with that of Ceyhan et al. (2008), Blamey et al. (1997) and Schon and Blevins (1990). They all are of the view that boron application is necessary in all those soils which are deficient in micronutrients. Moreover, Donald et al. (1998) suggested the foliar application as best mode of fertilizer application due to its better efficiency.

Qualitative traits. Protein and oil contents mainly contribute towards the yield of the plants and are affected by application of different micronutrients including boron. The decrease in protein and oil contents at higher dose might be due to burning of the leaves that affected its photosynthetic performance and other physiological functions. Boron has been found to play a key role in nitrogen metabolism and assimilation (Ruiz et al., 1998; Shelp, 1988). Nitrogen is a primary constituent of protein as well as all enzymes (Raun and Johnson, 1999) and in this way boron application showed marked influence on protein and oil contents of grains. 


\section{Conclusion}

Present study highlighted the importance of boron application in soils which are boron deficient especially in Pakistan. Boron application nearly improved all the traits at dosage of 0.15 and $0.30 \mathrm{~kg} / \mathrm{ha}$, however, at higher dosage of $0.45 \mathrm{~kg} / \mathrm{ha}$ declining tendency was observed due to its toxic effect and caused burning of the leaves. Overall, boron@ $0.30 \mathrm{~kg} / \mathrm{ha}$ is recommended due to its role in improving growth and yield indices.

\section{References}

Ahmed, N., Abid, M., Ahmad, F. 2008. Boron toxicity in irrigated cotton (Gossypium hirsutum L.). Pakistan Journal of Botany, 40: 2443-2452.

Blamey, F.P.C., Zollinger, R.K., Schneiter, A.A. 1997. Sunflower production and culture; In: Sunflower Science and Tehnology. A. A. Schneiter (ed.), pp. 595-670, Agronomy Monograph 35, ASA, CSSA and SSSA Madison, WI, USA.

Bressani, R., Turcios, J.C., Ruiz, A.S.C., Palomo, P.P. 2004. Effect of processing conditions on phytic acid, calcium, iron, and zinc contents of lime-cooked maize. Journal of Agricultural Food Chemistry, 52: 1157-1162.

Ceyhan, E., Onder, M., Ozturk, O., Harmankaya, M., Hamurcu, M., Gezgin, S. 2008. Effects of application boron on yields, yield component and oil content of sunflower in boron-deficient calcareous soils. African Journal of Biotechnology, 7: 2854-2861.

Ceyhan, E., Onder, M., Harmankaya, M., Gezgin, S. 2007. Response of chickpea cultivars to application of boron in boron-deficient calcareous soils. Communication in Soil Science, Plant and Analysis, 38: 1-19.

Dell, B., Huang, L. 1997. Physiological response of plants to low boron. Plant and Soil, 193: 103-120.

Donald, D.H., Gwathmey, C.O., Carl, E.S. 1998. Foliar feeding of cotton: Evaluating potassium sources, potassium solution buffering and boron. Agronomy Journal, 90: 740-746.

Gupta, U.C. (ed.). 1993. Source of boron. In: Boron and its Role in Crop Production. Agriculture and Agri-Food Canada. Charlottetown Saskatchewan, Canada.
Gupta, U.C., Jame, Y.W., Campbell, C.A., Leyshon, A.J., Nicholaichuk, W. 1985. Boron toxicity and deficiency: a review. Canadian Journal of Soil Science, 65: 381-409.

Hussain, M.Z., Rehman, N., Khan, M.A., Roohullah, Ahmed, S.R. 2006. Micronutrients status of Bannu basen soils. Sarhad Journal of Agriculture, 22: 283-285.

Lopez-Lefebre, L.R., Rivero, R.M., Garcia, P.C., Sanchez, E., Ruiz, J.M., Romero, L. 2002. Boron effect on mineral nutrition of tobacco. Journal of Plant Nutrition, 25: 509-522.

Mazher, A.M., Zaghloul, S.M., Yassen, A.A. 2006. Impact of boron fertilizer on growth and chemical constituents of Taxodium distichum grown under water regime. World Journal of Agricultural Sciences, 2: 412-420.

NNS. 2008. National Nutrition Survey, 2007-2008. Planning Commission, Government of Pakistan, Islamabad, Pakistan.

Raun, W.R., Johnson, G.V. 1999. Improving nitrogen use efficiency for cereal production. Agronomy Journal, 91: 357-363.

Ruiz, J.M., Baghour, M., Bretones, G., Belakbir, A., Romero, L. 1998. Nitrogen metabolism in tobacco plants (Nicotiana tabacum L.): Role of boron as a possible regulatory factor. International Journal of Plant Sciences, 159: 121-126.

Schon, M., Blevins, D. 1990. Foliar boron applications increase the final number of branches and pods on branches of field-grown soybeans. Plant Physiology, 92: 602-605.

Shelp, B.J. 1988. Boron mobility and nutrition in broccoli (Brassica oleracea var. italica). Annals of Botany, 61: 83-91.

Sherrell, C.G. 1983. Boron deficiency and response in white and red clovers and lucerne. New Zealand Journal of Agricultural Research, 26: 197-203.

Shorrocks, V.M. 1997. The occurrence and correction of boron deficiency. Plant and Soil, 193: 121-148.

Steel, G.R., Torrie, H.J., Dickey, A.D. 1997. Principals and Procedures of Statistics. A Biometrical Approach. pp. 400-428, $3^{\text {rd }}$ edition, McGraw Hifi Book Co. Inc., New York, USA. 